\title{
Barbie Boy
}

\section{Jacinta Cole}

'THIS PERSON, 'ERE' the principal's finger hovered over the figure beside me. 'They dun' have much hair, do they?'

'No sir.'

'Why's that?' I shrugged my shoulders.

'Is it a lady? Ladies normally wear dresses, dun' they?'

'Yes sir.'

'Right. So this ain't a lady. This is a man.'

'I guess so.'

Silence. Principal Crawley cleared his throat. 'Boys ain't supposed to like other boys, son. That's not what God intended.' I nodded, keeping my eyes fixed to the ground.

'The school can't condone this sort of behaviour on a regular basis.' He sat behind his desk and smiled an encouraging smile across at my parents. 'No need ter worry, though. I'm sure it's just a phase Nick's goin' through.'

No one spoke on the ride home.

Four years later, my old man dragged me by the arm into our local church, the only significant building in our small country town. It stood alone on a stretch of dirt road, gleaming white like a set of teeth waiting to eat me alive. I walked into that church, with the eyes of God himself staring down at me from the stained glass windows and waited for Hell to swallow me whole. It felt as though the floor was about to open up with each step I took. The place was empty except for me and my pa, and there was nowhere to run from his searing gaze, his disappointment and disapproval burning the back of my neck. I gulped and moved towards the confessional box, just like he told me to and poured my heart out to the priest about what a bad thing I'd done, how I'd tried to kiss my friend Tim behind the trees near my house. 
I lay in the bath with the water up to the tip of my chin, surrounded by naked dolls. My little sister shared them with me sometimes. She just giggled and called me Barbie Boy because she was too young to understand the concept of my faulty moral compass. That's what the priest called it. He said I was just out of whack right now and needed to be realigned. I remembered the story he once read about the baptism and how Jesus washed away sins in the river. I thought maybe I could do the same, wash away the bad thoughts and become normal again. Maybe it would soak into me, maybe I could cleanse myself. Maybe if I looked at the dolls long enough, I'd see girls the same way the other boys did. I closed my eyes, took a deep breath and slipped under the water, watching their bodies blur at the surface. My old man found me, and the look on his face; I swear it was like looking down the barrel of a gun. He and Ma started ripping into each other in the kitchen. I heard the fly screen door slam and the growl of tyres as pa drove off. I plunged myself underwater and tried to block out the ringing in my ears.

Later, when I asked Ma if he was coming back, she just stared silently out the kitchen window twisting the wedding ring 'round her finger, sniffling quietly to herself.

I never meant to hurt anyone.

By the time I was sixteen I was tired of being the outcast. I got myself a girlfriend in the hope that she would get this thing out of my system.

At a neighbour's party, bottle of whiskey in hand, she took the lead; forcing me into a room away from the rest of the crowd. She got to work quickly, kissing at my neck and ears, her fingers tracing their way from my chest to the rim of my jeans. But it felt wrong. Empty. I had to draw her head up from my lap before she could get any further.

'You lying prick. Shoulda known I couldn't change ya.'

I left while she shouted expletives at me, but I didn't get very far from the house. Along a back street, I heard footsteps coming up behind me. 'Hey faggot!' 
I swung 'round to see Brad and his crew striding towards me, with dirty smirks on their faces. 'Where the fuck you think you're runnin' to?'

They'd hunted me down. Before I had time to move, I felt a blow to my stomach and I was on the ground, fists slamming into me from all directions. Someone's foot connected with my ribs; I felt the shatter, the crunch of bone. My lungs gasped for air as I clawed and squirmed, desperate to get away, unable to fight back no matter how hard I tried. My head throbbed, reducing Brad and his cronies to fuzzy shapes dancing around me. Blood was streaming from my nose, caked to the corners of my mouth and trickling down my neck. I struggled but it was no use - the booze had made me weak and clumsy. Two of them grabbed hold of my arms and wrenched them behind me. They jerked my head up by my hair until I was face to face with Brad's crotch.

'What's that faggot? You hungry?'

He opened the zipper and fumbled with his pants until his cock was exposed. It reeked of sweat and piss as he shoved it in my face. I couldn't move because my head was being forced down. He pushed his dick past my lips and I choked and gagged as he shoved it down my throat. The other boys were howling. I couldn't breathe. He had the worst gleam in his eyes. I tried to focus on something else, anything to get me away from there. The flickering street light, the overflowing dumpster, the dogs barking from the backyards of ordinary heterosexual families. Brad was grunting, hissing through his teeth and then he was done, it was over, and I thanked the God that hates me, as he spilt his load into my mouth. He smacked my head against the wall and spat on me as they left.

I found myself back in the bathroom of my house, staring into the water filled once more with naked dolls. Reduced to a child again. My reflection in the mirror repulsed me. I'd never felt dirtier, more ashamed. The priest said I should have expected something like this. The water scalded my skin as I stepped in. I plunged beneath the dolls again, relaxing as the water rushed over me. This time I didn't worry about coming up for air. 